\title{
Anaesthesia workstation monitor: why surgeons should monitor?
}

\author{
Mantu Jain (1) , ${ }^{1}$ Aparajita Panda, ${ }^{2}$ Barun Patel, ${ }^{3}$ Ssamy C Ajay ${ }^{3}$
}

${ }^{1}$ Department of Orthopaedics, All India Institute of Medical Sciences, Bhubaneswar, India ${ }^{2}$ Anaesthesia, All India Institute of Medical Sciences, Bhubaneswar, Orissa, India ${ }^{3}$ Department of Orthopaedics, All India Institute of Medical Sciences, Bhubaneswar, Orissa, India

Correspondence to Dr Mantu Jain; montu_jn@yahoo.com

Accepted 3 August 2021
Check for updates

(C) BMJ Publishing Group Limited 2021. No commercial re-use. See rights and permissions. Published by BMJ.

To cite: Jain $\mathrm{M}$, Panda $\mathrm{A}$ Patel $\mathrm{B}$, et al. BMJ Case Rep 2021;14:e244932. doi:10.1136/bcr-2021244932

\section{DESCRIPTION}

Spinal surgery carries an inherent risk of injury to the neural elements. Real-time intraoperative guidance such as neuromonitoring can substantially improve the safety and efficacy of spinal surgery. ${ }^{1}$

A 32-year-old man, case of cervical spondylotic myelopathy (CSM), Nurick's grade 3 with focal ossified posterior longitudinal ligament at C6, American Society of Anaesthesiologist grade 1 , was posted for single-level corpectomy. The patient has a heart rate (HR) of $60 / \mathrm{min}$ and blood pressure of $110 / 80 \mathrm{~mm} \mathrm{Hg}$ on the right arm. The surgery went on smoothly, but postsurgery, we noted that he had increased tonicity in his bilateral lower limb and had bradycardia. An urgent CT scan showed a loose piece of bone impinging the cord (figure 1A). However, any signs of lateralisation were absent. The next day, an emergent re-exploration was done, and the anaesthesia workstation monitor showed a pulse rate of range $46-48 / \mathrm{min}$ (figure $1 \mathrm{~B}$ ). The piece was challenging to localise intraoperatively. However, the corpectomy window was enlarged, and a suspected bony part adhered to the duramater was removed. As we started the closure with lots of anxiety and fingers crossed, we noted a change in the HR that increased to 90/ min, as shown in the monitor (figure 2A). This was the subtle indicator of a successful surgery, and our anaesthesia monitor guided us akin to intraoperative neuromonitoring (IONM). A repeat postoperative CT confirmed the excision of the bony piece (figure 2B), and the patient had a dramatic improvement in his tone the following day.

The goal of any spinal surgery is preventing further neurological deterioration, although achieving some functional recovery. ${ }^{2}{ }^{3}$ IONM is integral in predicting intraoperative cervical cord function changes in CSM. ${ }^{4}$ Severe
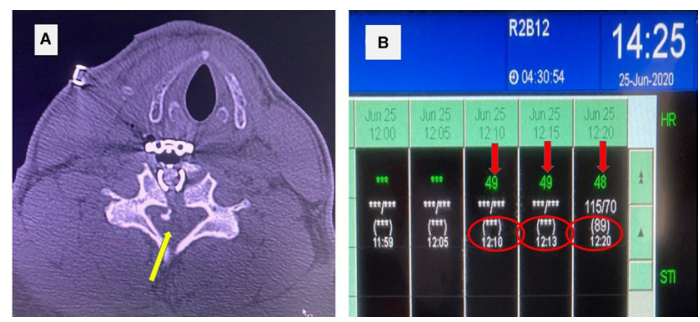

Figure 1 (A) CT scan showing the bone piece impinging the spinal cord (yellow arrows). (B) Monitor showing the heart rate with bradycardia (red arrow) and time highlighted with red circles.

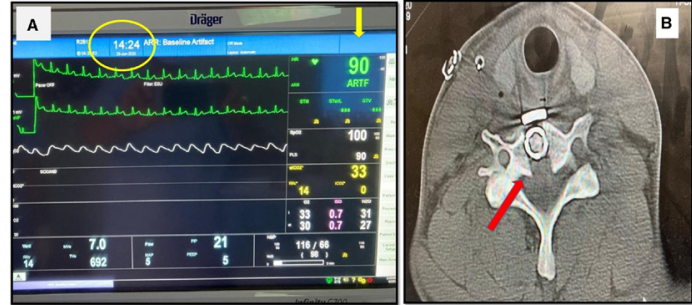

Figure 2 (A) Postremoval improvement in heart rate with time (highlighted in yellow). (B) CT scan after removing a bone piece.

\section{Learning points}

- Intraoperative neuromonitoring is valuable in operating complex spine surgery.

- The role in cervical myelopathy may be beneficial, but it is not widely available in all set-ups.

- A regular anaesthesia monitor can provide subtle hints for the successful completion of decompression.

compression of the descending motor tracts can be picked up as abnormalities of the intraoperative motor evoked potentials (MEPs) by IONM. ${ }^{3}$ But today's IONM has multiple neuromonitoring modalities that include somatosensory evoked potentials, MEPs, spontaneous electromyography and triggered electromyography. A careful interpretation of these combined modalities can maximise the sensitivity and specificity in detecting impending neural injury. ${ }^{5}$ In developing countries, the universal availability of the IONM is a significant limitation, especially in the emergency theatre. ${ }^{6-8}$ But, the anaesthesia monitoring is routine in all cases. A visible documented change can be satisfying to the whole surgical team when there are no other ways to confirm intraoperatively. We had not kept an image of the preoperative anaesthesia monitor findings during the revision surgery, but we retrieved the old readings once we observed an improvement. The purpose of the article is to highlight this critical finding wherein our 'regular' anaesthesia monitor saved our day.

Contributors MJ, BP and SCA were operating surgeons on two occasions where AP was the anaesthetist. BP and SCA reviewed the literature and $\mathrm{MJ}$ and $\mathrm{AP}$ wrote the manuscript. All authors agree to the content of the manuscript. 
Images in...

Funding The authors have not declared a specific grant for this research from any funding agency in the public, commercial or not-for-profit sectors.

Competing interests None declared.

Patient consent for publication Obtained.

Provenance and peer review Not commissioned; externally peer reviewed.

\section{ORCID ID}

Mantu Jain http://orcid.org/0000-0003-3848-4277

\section{REFERENCES}

1 Lall RR, Lall RR, Hauptman JS, et al. Intraoperative neurophysiological monitoring in spine surgery: indications, efficacy, and role of the preoperative checklist. Neurosurg Focus 2012;33:E10.
2 Hochman M, Tuli S. Cervical spondylotic myelopathy: a review. Internet J Neurol 2005;4:24-42.

3 Lo YL, Zhu L, Soh RC, et al. Intraoperative motor evoked potential improvement in cervical spondylotic myelopathy: comparison of cortical stimulation parameters. J Clin Neurol 2020;16:102-7.

4 Wang S, Ren Z, Liu J, et al. The prediction of intraoperative cervical cord function changes by different motor evoked potentials phenotypes in cervical myelopathy patients. BMC Neurol 2020:20:221.

5 Gonzalez AA, Jeyanandarajan D, Hansen C, et al. Intraoperative neurophysiological monitoring during spine surgery: a review. Neurosurg Focus 2009;27:E6.

6 Guiroy A, Valacco M, Gagliardi M, et al. Barriers of neurophysiology monitoring in spine surgery: Latin America experience. Surg Neurol Int 2020;11:130.

7 Mayilvaganan S, Chaurasia A, Mahalakshmi D. Poor Man's Intraoperative Neuromonitoring in Thyroid Surgery. World J Endoc Surg 2020;12:105-7.

8 Netto MB, Neto MI, Ferreira RJ. The reality of using intraoperative neurophysiologic monitoring among Brazilian spine surgeons. Coluna Columna 2012;11:310-4.

Copyright 2021 BMJ Publishing Group. All rights reserved. For permission to reuse any of this content visit

https://www.bmj.com/company/products-services/rights-and-licensing/permissions/

BMJ Case Report Fellows may re-use this article for personal use and teaching without any further permission.

Become a Fellow of BMJ Case Reports today and you can:

- Submit as many cases as you like

- Enjoy fast sympathetic peer review and rapid publication of accepted articles

- Access all the published articles

Re-use any of the published material for personal use and teaching without further permission

\section{Customer Service}

If you have any further queries about your subscription, please contact our customer services team on +44 (0) 2071111105 or via email at support@bmj.com.

Visit casereports.bmj.com for more articles like this and to become a Fellow 